\title{
GENETIC RELATIONSHIPS AMONG SOME SPECIES GROUPS WITHIN THE GENUS LUTZOMYIA (DIPTERA: PSYCHODIDAE)
}

\author{
DARA G. TORGERSON, MARGARITA LAMPO, YELITZA VELÁZQUEZ, AND PATRICK T. K. WOO \\ Centro de Ecología, Instituto Venezolano de Investigaciones Científicas, Caracas, Venezuela; Department of Biology, McMaster \\ University, Hamilton, Ontario, Canada; Department of Zoology, University of Guelph, Guelph, Ontario, Cannada
}

\begin{abstract}
Molecular data on Lutzomyia are very scarce, despite the fact that this genus includes all the species involved in the transmission of leishmaniasis in America. We examine the genetic relationships among eight morphologic groups within the Lutzomyia genus and two Brumptomyia species, using nine enzyme loci and the last 285 basepairs of the mitochondrial cytochrome $b$ gene. The structure of the genetic variation among the species analyzed indicated a closer genetic relationship among members of a morphologic group than between members of different groups. The lower levels of variation recorded among these groups compared with that between Brumptomyia and Lutzomyia suggest a subgeneric status for all of these groups, including Psychodopygus. A maximum likelihood tree for the allozyme data and a neighbor-joining consensus tree for the mitochondrial DNA sequences showed a general agreement with morphologic groups, with only minor differences. Nyssomyia, Verrucarum and Micropygomyia formed separate monophyletic groups. Lutzomyia could not be separated from Psathyromyia, and both Migonei species, L. dubitans and L. migonei, grouped in different clades according to the host species they are found on.
\end{abstract}

\section{INTRODUCTION}

Lutzomyia is the largest phlebotomine genus and contains more than 400 species and subspecies, including all American sand flies involved in the transmission of leishmaniasis. ${ }^{1}$ Classification within this genus is still controversial because the accepted taxonomic groupings are based on morphologic characters that exhibit a great deal of variation among species, but fail to separate distinct groups. ${ }^{2-5}$ For example, a single morphologic character may have a specific rank in one group, and a group rank in another. ${ }^{4}$ Also, a species may appear more closely related to one group according to one sex but to a different group according to the other sex. The absence of a common character within groups results in several opinions on the weightings of each character, and therefore the stability of taxonomic groups. Conversely, there are controversial opinions about the supraspecific rank of some of these groups, as is the case for Psychodopygus. Ready and others ${ }^{5}$ have argued that Psychodopygus differs sufficiently from other New World species to conform its own genus separated from the Lutzomyia; however, other investigators disagree with this position. .,2 $^{1}$

Although phylogenetic relationships based on molecular data have been constructed for many Phlebotomus species, ${ }^{6}$ for Lutzomyia, the molecular evidence comes from few representative species. For example, using the D2 domain of ribosomal DNA, Dujardin and others ${ }^{7}$ suggested the monophyly of three Lutzomyia species (L. longipalpis, L. migonei, and L. youngi) in relation to some species from the Phlebotomus and Sergentomyia genera. Moreover, based on isozyme evidence, Dujardin and others ${ }^{8}$ suggested a closer relationship between Lutzomyia and Phlebotomus, both genera involved in the transmission of Leishmania, than between Phlebotomus and other Old World genera. More recently, two studies exploring the relationship between species groups within the Lutzomyia genera were published. ${ }^{9,10}$ One of these studies questioned the monophyletic status of the Lutzomyia subgenus and the Migonei group using a gene involved in the production of acoustic signals used during courtship in Lutzomyia. ${ }^{9}$ The other study also failed to find support for the monophyly of these two groups using a different gene involved in both biologic rhythms and courtship song. ${ }^{10}$ How- ever, since molecular data is still limited for New World species, the genetic relationships among accepted morphologic groups within the Lutzomyia genus are poorly known.

DNA sequences and allozyme loci provide two independent genetic markers by which the cohesion of morphologic taxonomic groupings may be tested. Here we examine the genetic relationships among 20 species of Lutzomyia and Brumptomyia using nine allozyme loci and the last 285 basepairs of the mitochondrial cytochrome $b$ gene. A previous study suggested the topologies of trees based on this gene reflect the phylogenetic relationship between species rather than populations. ${ }^{11}$ In the transmission of different forms of leishmaniasis, phlebotomine species form transmission cycles with specific associations between Leishmania parasites, vector species and vertebrate hosts, and unique epidemiologic patterns. Thus, the genetic relationships between Lutzomyia vectors and non-vectors species seem fundamental for the understanding of the evolution of zoonotic transmission cycles. $^{12}$

\section{MATERIALS AND METHODS}

Study sites. Adult sand flies were collected from eight locations across the northern basin of Venezuela and were transported to the laboratory in liquid nitrogen (Table 1). The head and distal abdominal tergites were separated and stored in $70 \%$ ethanol, whereas the remaining thorax and proximal tergites were stored at $-70^{\circ} \mathrm{C}$. The head and abdominal tergites were digested at $60^{\circ} \mathrm{C}$ for 10 minutes in either $10 \% \mathrm{KOH}$ or Nesbitt solution (40 grams of chloralhydrate crystals, 10 $\mathrm{mL}$ of $\mathrm{HCl}$, and $40 \mathrm{~mL}$ of water), then cleared in $100 \%$ phenol. Specimens were mounted in Berlese medium and examined under the light microscope. Species diagnosis was based mainly on the morphology of female structures (cibarium, pharynx, teeth, and spermathecae), and of the male terminalia. ${ }^{1}$

Allozyme analysis. Ninety-nine individuals from nine species were processed using standard vertical acrylamide gel electrophoresis as previously described. ${ }^{12}$ An Aedes aegypti (L.) (Rockefeller strain) was included in each electrophoresis as a standard reference. Two continuous buffer systems were used to maximize allelic separation, Tris-citrate, $\mathrm{pH} 7.1$, and 
TABLE 1

Taxonomic relationships among the 20 phlebotomine sandfly species used in this study

\begin{tabular}{|c|c|c|c|}
\hline Genus & Subgenus or species group & Species & Source \\
\hline \multirow[t]{18}{*}{ Lutzomyia } & \multirow[t]{3}{*}{ Lutzomyia } & Lutzomyia longipalpis (Lutz \& Neiva) & $\begin{array}{l}\text { Altagracia } \\
9^{\circ} 52^{\prime} \mathrm{N}, 66^{\circ} 23^{\prime} \mathrm{W}\end{array}$ \\
\hline & & Lutzomyia pseudolongipalpis (Arrivillaga \& Feliciangeli) & $\begin{array}{l}\text { La Rinconada } \\
9^{\circ} 59^{\prime} \mathrm{N}, 69^{\circ} 55^{\prime} \mathrm{W}\end{array}$ \\
\hline & & Lutzomyia gomezi (Nitzulescu) & $\begin{array}{l}\text { El Ingenio } \\
10^{\circ} 31^{\prime} \mathrm{N}, 66^{\circ} 34^{\prime} \mathrm{W}\end{array}$ \\
\hline & \multirow[t]{2}{*}{ Migonei } & Lutzomyia migonei (Franca) & El Ingenio \\
\hline & & Lutzomyia dubitans (Sherlock) & El Ingenio \\
\hline & \multirow[t]{2}{*}{ Verrucarum } & Lutzomyia ovallesi (Ortiz) & El Ingenio \\
\hline & & Lutzomyia townsendi (Ortiz) & $\begin{array}{l}\text { Altos de Pipe } \\
10^{\circ} 20^{\prime} \mathrm{N}, 66^{\circ} 55^{\prime} \mathrm{W}\end{array}$ \\
\hline & \multirow[t]{3}{*}{ Psathyromyia } & Lutzomyia abonnenci (Floch \& Chassignet) & $\begin{array}{l}\text { El Pilón } \\
9^{\circ} 45^{\prime} \mathrm{N}, 68^{\circ} 34^{\prime} \mathrm{W}\end{array}$ \\
\hline & & Lutzomyia punctigeniculata (Floch \& Abonnenc) & El Ingenio \\
\hline & & Lutzomyia shannoni (Dyar) & El Pilón \\
\hline & \multirow[t]{2}{*}{ Nyssomyia } & Lutzomyia hernandezi (Ortiz) & $\begin{array}{l}\text { El Vigia } \\
8^{\circ} 43^{\prime} \mathrm{N}, 71^{\circ} 39^{\prime} \mathrm{W}\end{array}$ \\
\hline & & Lutzomyia whitmani (Antunes and Coutinho) & $\begin{array}{l}\text { Ready et al. } 1997 \\
\text { Accession Number: U80966 }\end{array}$ \\
\hline & Psychodopygus & Lutzomyia panamensis (Shannon) & $\begin{array}{l}\text { San Esteban } \\
10^{\circ} 26^{\prime} \mathrm{N}, 68^{\circ} 01^{\prime \prime} \mathrm{W}\end{array}$ \\
\hline & \multirow[t]{3}{*}{ Micropygomyia } & Lutzomyia absonodonta (Feliciangeli) & $\begin{array}{l}\text { Mapire } \\
7^{\circ} 44^{\prime} \mathrm{N}, 64^{\circ} 42^{\prime} \mathrm{W}\end{array}$ \\
\hline & & Lutzomyia cayennensis (Floch and Abonnenc) & El Ingenio \\
\hline & & Lutzomyia venezuelensis (Floch and Abonnenc) & $\begin{array}{l}\text { Rancho Grande } \\
10^{\circ} 22^{\prime} \mathrm{N}, 67^{\circ} 41^{\prime} \mathrm{W}\end{array}$ \\
\hline & Oswaldoi & Lutzomyia trinidadensis (Newstead) & El Ingenio \\
\hline & Ungrouped & Lutzomyia rangeliana (Ortiz) & Altagracia \\
\hline \multirow[t]{2}{*}{ Brumptomyia } & & Brumptomyia beaupertuyi (Ortiz) & Rancho Grande \\
\hline & & Brumptomyia devenanzii (Ortiz and Scorza) & Altos de Pipe \\
\hline
\end{tabular}

Tris-borate-EDTA, pH 8.9. Five enzyme loci were resolved in Tris-citrate, $\mathrm{pH}$ 7.1: adenylate kinase ( $A k$, E.C.2.7.4.3), arginine kinase (Ark, E.C.2.7.3.3), isocitrate dehydrogenase (Idh, E.C. 1.1.1.42), glycerol-3-phosphate dehydrogenase ( Gpd, E.C. 1.1.1.8), malate dehydrogenase (Mdh, E.C. 1.1.1.37) and phosphoglucomutase (Pgm, E.C.5.4.2.2). Four loci were resolved in Tris-borate-EDTA $\mathrm{pH}$ 8.9: fumarate hydratase (Fum, E.C.4.2.1.2), glucose-6-phosphate isomerase (Gpi, E.C.5.3.1.9), hexokinase ( $H k$, E.C.2.7.1.1) and malic enzyme (Me, E.C.1.1.1.40). In addition, allele frequencies previously published from 157 individuals from nine other species were included in the analysis. ${ }^{13}$

Allozyme data was analyzed using the Fortran program BIOSYS-1. ${ }^{14}$ Genotypic frequencies were tested for HardyWeinberg equilibrium using a chi-square test, and Rogers genetic distances were calculated between pairs of species within groups, between pairs of species from different groups, and between pairs of species from different genera. After testing for normality of their distribution and homogeneity of their variances, the genetic distances were compared using analysis of variance (ANOVA) and Bonferroni post-hoc comparisons. ${ }^{15}$ The cohesion of the subgeneric species groups classically accepted was explored using a maximum likelihood tree obtained from the program Phylip. ${ }^{16}$ For this analysis, we excluded groups for which only one species was available because the maximum likelihood analysis would force these species, in the absence of partners from their own groups, into other groups.

Sequencing of DNA. A total of 26 specimens from 13 species were sequenced for the last 285 basepairs of the mitochondrial cytochrome $\mathrm{b}$ gene. The cytochrome $\mathrm{b}$ sequence from $L$. whitmani ${ }^{3}$ was obtained from the National Center for Biotechnology Information (Bethesda, MD) (http:// www.ncbi.nlm.nih.gov), accession number U80966.

Total genomic DNA was extracted from each sand fly using a proteinase K solution. Each sand fly (thorax plus abdominal tergites) was rehydrated for approximately 10 minutes in 500 $\mu \mathrm{L}$ of distilled water, or until it sank to the bottom of the water column. Proteinase $\mathrm{K}$ was dissolved in distilled water to give a concentration of $20 \mathrm{mg} / \mathrm{ml}$ and stored at $-20^{\circ} \mathrm{C}$ until use. Ten milliliters of extraction buffer was prepared using $100 \mu \mathrm{L}$ of the proteinase $\mathrm{K}$ dilution, $100 \mu \mathrm{L}$ of $1 \mathrm{M}$ Tris- $\mathrm{HCl}, \mathrm{pH} 8.3$, $500 \mu \mathrm{L}$ of $1 \mathrm{M} \mathrm{KCl}, 50 \mu \mathrm{L}$ of $1 \%$ Tween 20 solution, $50 \mu \mathrm{L}$ of $1 \%$ Nonidet P40, and $9.2 \mathrm{~mL}$ of double-distilled water. Individual sand flies were transferred into $100 \mu \mathrm{L}$ of the proteinase $\mathrm{K}$ solution and ground using a pestle. Samples were vortexed and then incubated at $50^{\circ} \mathrm{C}$ overnight for approximately 15 hours, then held at $95^{\circ} \mathrm{C}$ for 10 minutes to denature the proteinase K. Samples were allowed to cool in a refrigerator, and then stored at $-20^{\circ} \mathrm{C}$ until amplification by a polymerase chain reaction (PCR).

A volume of $1-3 \mu \mathrm{L}$ of extracted DNA was added to each 50- $\mu \mathrm{L}$ PCR, which contained $10 \times$ PCR buffer (without $\mathrm{MgCl}_{2}$ ), $1.5 \mathrm{mM} \mathrm{MgCl}{ }_{2}, 500 \mu \mathrm{M}$ dNTP mixture, $300 \mathrm{ng}$ of each primer (forward and reverse), and one unit of Taq polymerase. A drop of mineral oil was added to the top of each reaction. The PCR was performed in a Perkin-Elmer (Norwalk, CT) thermal cycler according to the method of Ready and others, ${ }^{3}$ and included an initial denaturation step at $94^{\circ} \mathrm{C}$ for three minutes; five cycles at $94^{\circ} \mathrm{C}$ for 30 seconds, $40^{\circ} \mathrm{C}$ for 30 seconds, and $72^{\circ} \mathrm{C}$ for 1.5 minuters; 35 cycles at $94^{\circ} \mathrm{C}$ for 30 seconds, $44^{\circ} \mathrm{C}$ for 30 seconds, and $72^{\circ} \mathrm{C}$ for 1.5 minutes; a final 
extension period at $72^{\circ} \mathrm{C}$ for 10 minutes; and cooling to room temperature.

The forward primer (CB3-PDR) was 5'-CA(T/ C)ATTCAACC(A/T)GAATGATA-3' and the reverse primer (N1N-PDR) was 5'-GGTA(C/T)(A/T)TTGCCTCGA(T/A)TTCG(T/A)TATGA-3'; further descriptions of these primers are available. ${ }^{3}$ Positive reactions were purified using a High Pure PCR Product Purification Kit (catalog no. 1732668; Boehringer Mannheim, Indianapolis, IN). DNA was sequenced with both the CB3-PDR and N1N-PDR primers for each individual sand fly on an ABI 377 automated sequencer (Applied Biosystems, Foster City, CA) using the Taq FS dye rhodamine sequencing kit (Applied Biosystems). Sequences were confirmed using a basic alignment search tool (BLAST) (www URL http://www.ncbi.nlm.nih.gov), and by comparing the sequences obtained from the CB3-PDR (forward) primer to the complemented and reversed sequences obtained from the ND3-PDR (reverse) primer. DNA sequences were aligned using the program ClustalX, ${ }^{17}$ and compared with the translated amino acid alignment. To explore how the different taxonomic levels (species, subgenus, and genus) contribute to the variation of $F_{\mathrm{ST}}$, we performed an analysis of molecular variance (AMOVA) ${ }^{18}$ using the program ARLEQUIN version 2. ${ }^{19}$ The statistical significance of these contributions was tested by a permutation test implemented in the program. Genetic relationships were investigated using a neighbor-joining bootstrap consensus procedure with Kimura two-parameter distances using the program Phylip. ${ }^{16}$

\section{RESULTS}

Allozyme data. Allele frequencies varied among species (Appendix 1). Some loci were shared by groups of species, whereas for other loci we detected fixed differences between several species. Allele $M e$ was the most variable locus with nine alleles, and $A r k$ the least variable with only three alleles. Allele $H k^{0.89}$ separated both Brumptomyia species from all Lutzomyia species, and $M e^{0.83}$ was unique to L. panamensis. All other alleles were shared by species groups (Appendix 1).
Genetic variability measurements also differed among species. Mean heterozygosities ranged from $1.5 \%$ to $18.9 \%$ with 1.0-1.7 alleles per locus except for L. shannoni, which had fixed alleles for all loci. All populations complied with HardyWeinberg equilibrium expectations $(P \geq 0.05)$, indicating random mating within populations.

Genetic distances varied from 0.233 to 0.979 (Table 2). The largest distances were recorded between L. rangeliana (ungrouped) and L. shannoni (Psathyromyia group), and the smallest between $L$. venezuelensis and L. absonodonta, both members of the Micropygomyia group (Table 2). Genetic distances were normally distributed (intragroup KolgomorovSmirnov $[\mathrm{K}-\mathrm{S}]=0.115, P=0.967$; intergroup K-S $=0.047$, $P=0.991$; intergenera $\mathrm{K}-\mathrm{S}=0.135, P=0.471)$ and their variances were homogeneous $\left(\chi^{2}=2, P>0.1\right)$. Mean genetic distances for species within and between taxonomic groups are shown in Figure 1. The ANOVA showed that the taxonomic status of the species was a significant source of variation in the genetic distance between species $\left(F_{3,147}=9.55\right.$, $P<0.001)$. The post hoc Bonferroni test indicated that the genetic distance between species from different subgeneric groups within the Lutzomyia genus was significantly larger than that between species within each group (Figure 1). Conversely, we could not detect a significant difference in the mean genetic distances between species from different genera (Brumptomyia versus Lutzomyia) and between subgeneric groups (Figure 1). That is, allozyme variation increased significantly from species to subgenera but not from subgenera to genera.

A similar pattern of distribution of variation among hierarchical taxonomic levels was found in the $F$ statistics. Although the largest variance component in $F_{\mathrm{ST}}$ is explained by differentiation between species $(81.1 \%)$, there is an additional $19.9 \%$ that may be attributed to differences between subgeneric groups. However, once the species and subgenera level are considered, differences between genera had no contribution to the variance of $F_{\mathrm{ST}}$.

The maximum likelihood tree showed two distinct groups (Figure 2). The first group includes all the species of the

TABLE 2

Pairwise Rogers distance based on nine allozymic loci between 18 phlebotomine sandfly species from Venezuela*

\begin{tabular}{|c|c|c|c|c|c|c|c|c|c|c|c|c|c|c|c|c|c|c|}
\hline & bea & $d e v$ & ran & lon & plon & mig & $d u b$ & tow & pun & $a b o$ & sha & pan & atr & $a b s$ & cay & ven & yen & trin \\
\hline bea & - & & & & & & & & & & & & & & & & & \\
\hline dev & 0.432 & - & & & & & & & & & & & & & & & & \\
\hline ran & 0.850 & 0.783 & - & & & & & & & & & & & & & & & \\
\hline lon & 0.873 & 0.774 & 0.788 & - & & & & & & & & & & & & & & \\
\hline plon & 0.863 & 0.653 & 0.880 & 0.557 & - & & & & & & & & & & & & & \\
\hline mig & 0.661 & 0.681 & 0.697 & 0.832 & 0.680 & - & & & & & & & & & & & & \\
\hline$d u b$ & 0.789 & 0.578 & 0.665 & 0.769 & 0.746 & 0.621 & - & & & & & & & & & & & \\
\hline tow & 0.609 & 0.398 & 0.624 & 0.743 & 0.524 & 0.570 & 0.487 & - & & & & & & & & & & \\
\hline pun & 0.753 & 0.854 & 0.943 & 0.630 & 0.429 & 0.519 & 0.996 & 0.763 & - & & & & & & & & & \\
\hline$a b o$ & 0.806 & 0.793 & 0.928 & 0.350 & 0.468 & 0.690 & 0.901 & 0.766 & 0.558 & - & & & & & & & & \\
\hline sha & 0.885 & 0.885 & 0.979 & 0.440 & 0.579 & 0.542 & 0.882 & 0.864 & 0.439 & 0.423 & - & & & & & & & \\
\hline pan & 0.687 & 0.576 & 0.837 & 0.737 & 0.518 & 0.747 & 0.794 & 0.576 & 0.644 & 0.580 & 0.563 & - & & & & & & \\
\hline atr & 0.832 & 0.828 & 0.570 & 0.670 & 0.728 & 0.697 & 0.587 & 0.699 & 0.729 & 0.725 & 0.817 & 0.694 & - & & & & & \\
\hline$a b s$ & 0.671 & 0.460 & 0.675 & 0.650 & 0.530 & 0.729 & 0.568 & 0.275 & 0.747 & 0.680 & 0.774 & 0.451 & 0.609 & - & & & & \\
\hline cay & 0.961 & 0.751 & 0.609 & 0.730 & 0.584 & 0.580 & 0.506 & 0.546 & 0.708 & 0.736 & 0.617 & 0.676 & 0.527 & 0.459 & - & & & \\
\hline ven & 0.764 & 0.554 & 0.554 & 0.556 & 0.537 & 0.633 & 0.551 & 0.422 & 0.645 & 0.679 & 0.660 & 0.519 & 0.492 & 0.233 & 0.420 & - & & \\
\hline yen & 0.709 & 0.686 & 0.770 & 0.891 & 0.823 & 0.604 & 0.594 & 0.458 & 0.837 & 0.823 & 0.922 & 0.769 & 0.384 & 0.601 & 0.578 & 0.706 & - & \\
\hline tri & 0.583 & 0.580 & 0.721 & 0.642 & 0.677 & 0.746 & 0.714 & 0.645 & 0.528 & 0.673 & 0.758 & 0.497 & 0.432 & 0.484 & 0.775 & 0.467 & 0.637 & - \\
\hline
\end{tabular}

* Brumptomyia beaupertuyi (bea), B. devenanzii (dev), Lutzomyia rangeliana (ran), L. longipalpis (lon), L. pseudolongipalpis (plon), L. migonei (mig), L. dubitanss (dub), L. townsendi (tow), L. punctigeniculata (pun), L. abonnenci (abo), L. shannoni (sha), L. panamensis (pan), L. atroclavata (atr), L. absonodonta (abs), L. cayenensis (cay), L. venezuelensis (ven), L. yencannensis (yen), and L. trinidadensis (tri). 


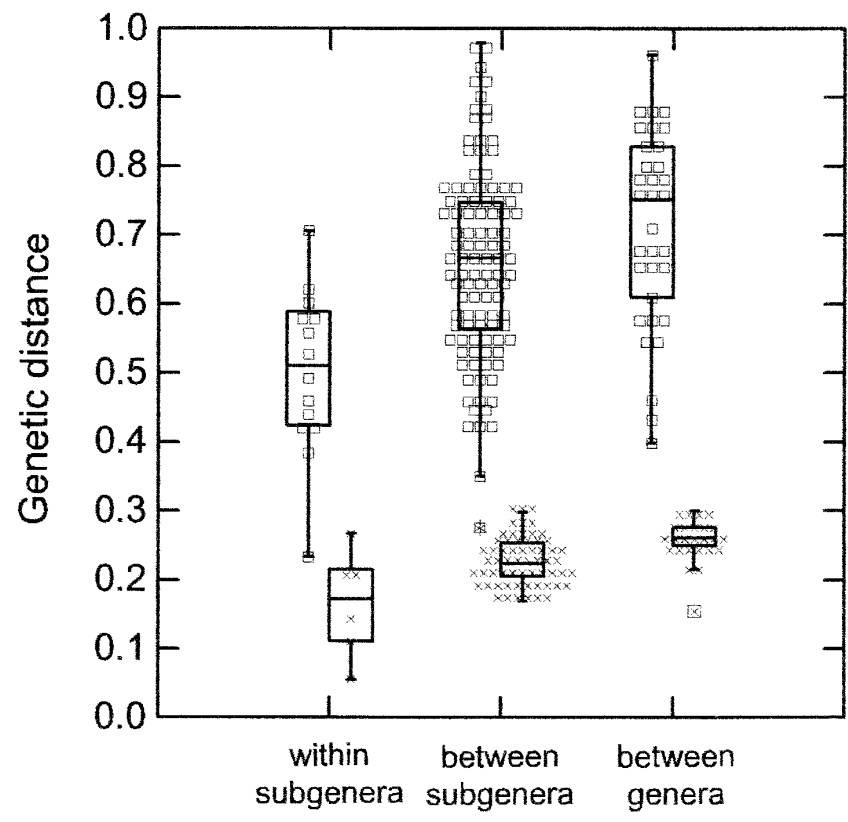

FIGURE 1. Genetic distances among species within subgeneric groups, between subgeneric groups, and between subgenera. The squares represent the Rogers distance based on nine allozyme loci and the $\times$ s represent the Kimura two-parameter distance using the last 285 basepairs of the mitochondrial cytochrome $b$ gene. The upper and lower limits of the boxes show the upper and lower quartiles. The horizontal line dividing each box is the median. The upper and lower limits of the vertical lines beyond the boxes show the largest and smallest observations within 1.5 interquartile ranges. Observations beyond these limits are plotted individually.

Micropygomyia group analyzed and one species of the Migonei group, L. dubitans. The second group intercalates species of the Lutzomyia and the Psathyromyia groups, including the other Migonei species, L. migonei.

DNA sequences. Cytochrome b sequences were deposited in GenBank under accession numbers AF448540- AF448546, and AY316731-AY316736. DNA sequences were successfully aligned and confirmed by eye using the amino acid alignment as a guide (Appendix 2). In every case, the two indi-

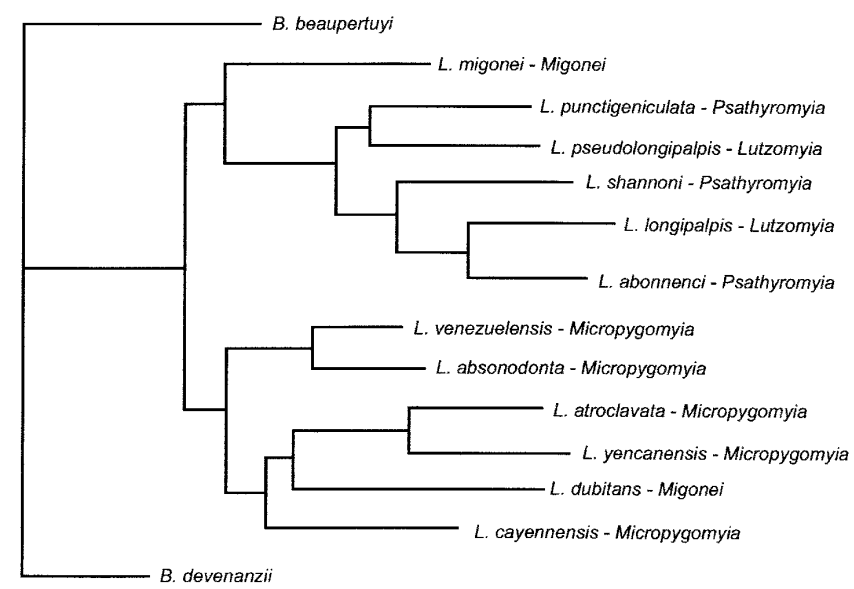

FIGURE 2. Maximum likelihood tree obtained from nine allozyme loci for 12 Lutzomyia and two Brumptomyia species from Venezuela. The input order was randomize with global rearrangements of species. Brumptomyia beaupertuyi was used as the outgroup. viduals that were sequenced from each species showed no sequence variation. The Kimura two-parameter genetic distances between species varied from 0.0554 to 0.3002 (Table 3). The smallest distance was recorded between both species from the Nyssomyia subgenus (L. hernandezi and L. whitmani) whereas the largest distances were between species from different genera ( $L$. gomezi and B. devenanzii). The mean genetic distance between species was larger between groups than within groups, and the mean distance between genera was larger than that between groups within each genus (Figure 1). An AMOVA indicated that $45.0 \%$ of the variation in the molecular distance may be explained by differentiation between species, $39.3 \%$ to differentiation between subgenera, and the residual $15.6 \%$, to differences between genera. Although the latter variance component is low, a permutation test on the genetic distance matrix showed that such a variance component could not be accounted for by random variation $(P<0.0279)$. This result indicates that variation in the DNA sequence analyzed increased significantly from species to subgenus, and from subgenus to genus.

The bootstrap consensus tree using neighbor-joining on the Kimura two-parameter distances showed two distinct evolutionary lineages with a high bootstrap value (99\%) for the Brumptomyia and Lutzomyia genera (Figure 3). At the subgeneric level, four groups were formed with high bootstrap confidence $(>80 \%)$. The Verrucarum and the Nyssomyia species each formed a monophyletic group, and the two cryptic species belonging to the Lutzomyia subgenus, L. longipalpis and L. pseudolongipalpis, similarly formed a monophyletic group. However, the status of L. gomezi, also from the Lutzomyia subgenus, was not resolved. Lutzomyia panamensis from the Psychodopygus subgenus, which has been proposed as a distinct genus rather than subgenus, grouped together with the Nyssomyia species, with genetic distances much smaller than those between the well defined genera of Brumptomyia and Lutzomyia. All other species placements were unresolved by the cytochrome $b$ fragment.

\section{DISCUSSION}

Three specific questions were addressed to explore the genetic relationships between the eight species groups analyzed: 1 ) is the genetic variation among the morphologic groups adopted by taxonomists different than that expected by random grouping of the species?, 2) are the levels of genetic variation observed among groups comparable to those found between different genera?, and 3) are the groups formed using phylogenetic trees consistent with the morphologic groups?

First, both allozyme data and DNA sequences from the mitochondrial cytochrome $b$ gene showed levels of genetic variation between the morphologic groups that could not be explained solely by the random grouping between species. The groups classically adopted by Lutzomyia taxonomists accounted for a significant proportion of the genetic variation among species because the genetic distances recorded between members of a group were smaller than those recorded between members of different groups. The data indicates that morphologic species groups, to a certain extent, represent the genetic relationships among species.

Second, the smaller levels of DNA variation observed be- 
TABLE 3

Kimura two-parameter distances based on the last 285 basepairs of the mitochondrial cytochrome b gene between 13 phlebotomine sandfly species from Venezuela*

\begin{tabular}{|c|c|c|c|c|c|c|c|c|c|c|c|c|c|c|}
\hline & bea & $d e v$ & ova & tow & lon & plon & $t r i$ & mig & cay & gom & $d u b$ & whi & her & pan \\
\hline bea & - & & & & & & & & & & & & & \\
\hline dev & 0.154 & - & & & & & & & & & & & & \\
\hline$o v a$ & 0.258 & 0.249 & - & & & & & & & & & & & \\
\hline tow & 0.261 & 0.275 & 0.143 & - & & & & & & & & & & \\
\hline lon & 0.283 & 0.264 & 0.186 & 0.186 & - & & & & & & & & & \\
\hline plon & 0.278 & 0.249 & 0.187 & 0.182 & 0.110 & - & & & & & & & & \\
\hline tri & 0.257 & 0.293 & 0.214 & 0.233 & 0.204 & 0.218 & - & & & & & & & \\
\hline mig & 0.223 & 0.214 & 0.168 & 0.186 & 0.195 & 0.190 & 0.223 & - & & & & & & \\
\hline cay & 0.245 & 0.254 & 0.223 & 0.224 & 0.262 & 0.263 & 0.252 & 0.204 & - & & & & & \\
\hline gom & 0.275 & 0.300 & 0.211 & 0.215 & 0.201 & 0.215 & 0.254 & 0.215 & 0.223 & - & & & & \\
\hline$d u b$ & 0.244 & 0.270 & 0.258 & 0.247 & 0.210 & 0.218 & 0.282 & 0.266 & 0.257 & 0.248 & - & & & \\
\hline whit & 0.289 & 0.238 & 0.223 & 0.262 & 0.210 & 0.233 & 0.282 & 0.209 & 0.287 & 0.245 & 0.243 & - & & \\
\hline her & 0.283 & 0.263 & 0.237 & 0.252 & 0.205 & 0.232 & 0.266 & 0.199 & 0.297 & 0.261 & 0.223 & 0.055 & - & \\
\hline pan & 0.262 & 0.258 & 0.190 & 0.227 & 0.199 & 0.228 & 0.287 & 0.209 & 0.256 & 0.275 & 0.252 & 0.186 & 0.173 & - \\
\hline
\end{tabular}

tween groups within Lutzomyia compared with those recorded between two of the recognized genera, Brumptomyia and Lutzomyia, suggests a subgeneric status as more adequate for these taxa than a generic one. Even for Psychodopygus, for which some investigators propose as a separate genus, the genetic evidence does not support a generic status for this subgenus. To treat the Psychodopygus as a separate genus may not adequately represent the close genetic relationships to the Lutzomyia species, particularly to the Nyssomyia group as seen in the cytochrome b gene fragment. Conversely, the allozyme data did not reveal any differences in the magnitude of the genetic variation between subgenera and genera. Allozymic differences not only tended to saturation below the genus level, but also the large variation intervals within subgenera masked the differences between subgenera and genera. We find that allozyme variation gives adequate resolution at the subgeneric level, but not at the generic level.

Third, the structure of groups shown in the trees agreed in general with the morphologic groups classically accepted, with only minor differences. The topography of the bootstrap consensus tree obtained with the DNA sequences showed

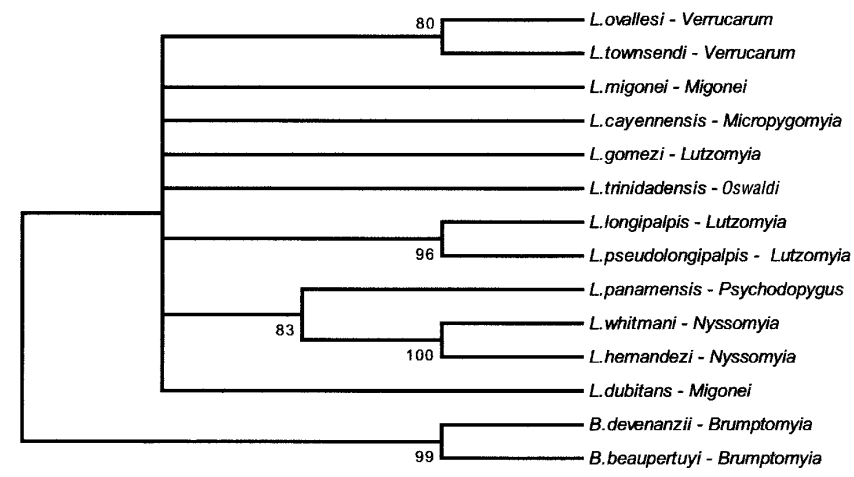

FIGURE 3. Neighbor-joining consensus tree of Kimura twoparameter distances based on the last 285 basepairs of the mitochondrial cytochrome b gene of two Brumptomyia and 12 Lutzomyia species from Venezuela. The numbers at each node represent the percent bootstrap support for 1,000 replicates; branches with bootstrap values less than $80 \%$ were collapsed. no inconsistencies with the morphologic groups, despite the fact that the positions of some species were not resolved by the DNA fragment used in this study. The clades with high bootstrap values grouped species within morphologic groups, as was the case for the Nyssomyia, Lutzomyia and Verrucarum groups. For the Nyssomyia group, a close genetic relationship between L. whitmani, L. intermedia, and L. umbratilis was previously reported using the period gene. ${ }^{10}$ The lack of resolution between Lutzomyia and Psathyromyia in the allozyme tree must be explored further with different genetic markers. Nonetheless, the distinct separation of the five Micropygomyia species from the Lutzomyia and Psathyromyia species suggests a close genetic relationship between the members of the Micropygomyia. Conversely, the position of both Migonei species suggests that this group could be polyphyletic, as suggested by the cacophony gene. ${ }^{9}$ It is worth noting that one of the Migonei species, L. dubitans, who is known to feed on lizards, grouped with the Micropygomyia species who have also been associated with feeding on reptiles. ${ }^{1}$ Similarly the other Migonei species, L. migonei who has been observed on domestic animals, clustered with a group well known for its domestic cycle, including the Lutzomyia and Psathyromyia subgenera. The lack of genetic data for most of the 400 species comprising the Lutzomyia genus with which to compare the results presented herein illustrates the need for more molecular data on this important taxonomic group.

Received February 13, 2003. Accepted for publication June 18, 2003.

Acknowledgments: We are grateful to Roy Danzmann for help with DNA sequencing and analysis, Milagros Rinaldi and Carmen Zulay Garcia for technical assistance, and Maria Dora Feliciangeli for assisting with the species identification. We also thank Luis Miguel Márquez and two anonymous reviewers for valuable comments on the manuscript.

Financial support: This study was supported by Consejo Nacional de Investigacions Cientificas y Tecnologicas (CONICIT) (No. 960001370), the World Health Organization-World Bank (No. 021007), the Canadian International Development Agency (CIDA), and the Canadian Bureau for International Education (CBIE).

Authors' addresses: Dara G. Torgerson, Department of Biology, McMaster University, 1280 Main Street West, Hamilton, Ontario, Canada, L8S 4K1, Telephone: 905-525-9140, Fax: 905-522-6066, 
E-mail: torgerdg@mcmaster.ca. Margarita Lampo and Yelitza Velázquez, Centro de Ecologia, Instituto Venezolano de Investigaciones Cientificas, Apartado 21827, Caracas 1020-A, Venezuela, Patrick T. K. Woo, Department of Zoology, University of Guelph, Guelph, Ontario, Canada, N1G 2W1.

\section{REFERENCES}

1. Young DG, Duncan MA, 1994. Guide to the Identification and Geographic Distribution of Lutzomyia Sand Flies in Mexico, the West Indies, Central and South America (Diptera: Psychodidae). Volume 2. Gainesville, FL: Associate Publishers.

2. Lewis DJ, Young DG, Fairchild GB, Minter DM, 1977. Proposals for a stable classification of the Phlebotominae sandflies (Diptera:Psychodidae). Syst Entomol 2: 319-332.

3. Ready PD, Day JC, de Souza AA, Rangel EF, Davies CR, 1997. Mitochondrial DNA characterization of populations of Lutzomyia whitmani (Diptera:Psychodidae) incriminated in the peri-domestic and silvatic transmission of Leishmania species in Brazil. Bull Entomol Res 87: 187-195.

4. Theodor O, 1965. On the classification of American phlebotominae. J Med Entomol 2: 171-197.

5. Ready PD, Fraiha H, Lainson R, Shaw JJ, 1980. Psychodopygus as a genus: reasons for a flexible classification of the phlebotomine sand flies (Diptera:Psychodidae). J Med Entomol 17: 7588.

6. Esseghir S, Ready PD, Killick-Kendrick R, Ben-Ismall R, 1997. Mitocondrial haplotypes and phylogeography of Phlebotomus vectors of Leishmania major. Insect Mol Biol 6: 211-225.

7. Dujardin JP, Le Pont F, Martinez E, 1999. Quantitative phenetics and taxonomy of some phlebotomine taxa. Mem Inst Oswaldo Cruz 94: 735-741.

8. Dujardin JP, Le Pont F, Cruz M, Leon R, Tarrieu F, Guderian R, Echeverria R, Tibayrenc M, 1996. Criptic speciation in Lutzomya (Nyssomyia) trapidoi (Fairchild \& Hertig) (Diptera: Psychodidae) detected by multilocus enzyme electrophoresis. Am J Trop Med Hyg 54: 42-45.

9. Lins RMMA, Oliveira SG, Souza NA, de Queiroz RG, Justiniano
SCB, Ward RD, Kyriacou CP, Peixoto AA, 2002. Molecular evolution of the cacophony IVS6 region in sandflies. Insect Mol Biol 11: 117-122.

10. Mazzoni CJ, Gomes CA, Souza NA, de Queiroz RG, Justiniano SCB, Ward RD, Kyriacou CP, Peixoto AA, 2002. Molecular evolution of the period gene in sandflies. J Mol Evol 55: 553562.

11. Testa JM, Montoya-Lerma J, Cadena H, Oviedo M, Ready PD, 2002. Molecular identification of vectors of Leishmania in Colombia: Mitochondrial introgression in the Lutzomyia townsendi series. Acta Trop. 84: 205-218.

12. Tesh RB, Guzman H, 1996. Sand flies and the agents they transmit. Beatty BJ, Marquadt WC, eds. The Biology of Disease Vectors. Niwot, CO: University Press of Colorado, 117-127.

13. Torgerson D, Lampo M, Woo PTK, 2000. Cellulose acetate vs. polyacrylamide enzyme electrophoresis for the identification of 13 species of phlebotomine sand flies (Diptera:Psychodidae) from Venezuela. J Med Entomol 38: 501-509.

14. Swofford DL, Selander RB, 1981. BIOSYS-1: a FORTRAN program for the comprehensive analysis of electrophoretic data in population genetics and systematics. J Hered 72: 281-283.

15. Sokal RS, Rohlf FJ, 1998. Biometry. The Principles and Practice of Statistics in Biological Research. New York: W. H. Freeman and Company.

16. Felsenstein J, 1993. PHYLIP (Phylogeny Inference Package) version 3.5c. Distributed by the author. Department of Genetics, University of Washington, Seattle, WA.

17. Thompson JD, Gibson TJ, Plewniak F, Jeanmougin F, Higgins DG, 1997. The CLUSTAL_X windows interface: flexible strategies for multiple sequence alignment aided by quality analysis tools. Nucleic Acids Res. 24: 4876-4883.

18. Excoffier L, Smouse P, Quattro J, 1992. Analysis of molecular variance inferred from metric distances among DNA haplotypes: application to human mitochondrial DNA restriction data. Genetics 131: 479-491.

19. Schneider S, Roessli D, Excoffier L, 2000. Arlequin version 2.000 . A software for population genetics data analysis. Available at http://anthropologie.unige.ch/arlequin/. 
APPENDIX 1

Allele frequencies of nine enzyme loci from the sandflies Brumptomyia beaupertuyi (bea), B. devenanzii (dev), Lutzomyia rangeliana (ran), L. longipalpis (lon), L. pseudolongipalpis (plon), L. migonei (mig), L. dubitanss (dub), L. townsendi (tow), L. punctigeniculata (pun), L. abonnenci (abo), L. shannoni (sha), L. panamensis (pan), L. atroclavata (atr), L. absonodonta (abs), L. cayenensis (cay), L. venezuelensis (ven), L. yencannensis (yen), and L. trinidadensis (tri)*

\begin{tabular}{|c|c|c|c|c|c|c|c|c|c|c|c|c|c|c|c|c|c|c|}
\hline & bea & $d e v$ & ran & lon & plon & $m i g$ & $d u b$ & tow & pun & $a b o$ & sha & pan & atr & $a b s$ & cay & ven & yen & $t r i$ \\
\hline \multicolumn{19}{|l|}{$A k$} \\
\hline $\mathrm{N}$ & 13 & 11 & 5 & 53 & 13 & 30 & 17 & 5 & 5 & 4 & 4 & 16 & 5 & 10 & 6 & 5 & 4 & 11 \\
\hline 1 & 0 & 0 & 0 & 0 & 0 & 0 & 0 & 0 & 0 & 0 & 0 & 0 & 0 & 0 & 0 & 0 & 0 & 0.36 \\
\hline 2 & 1.00 & 0 & 0 & 0 & 0 & 0 & 0 & 0 & 0 & 0.38 & 0 & 0 & 0 & 0 & 0 & 0 & 0 & 0 \\
\hline 3 & 0 & 1.00 & 0 & 0 & 1.00 & 0 & 1.00 & 1.00 & 0.10 & 0.50 & 0 & 1.00 & 1.00 & 1.00 & 1.00 & 1.00 & 1.00 & 0.64 \\
\hline 4 & 0 & 0 & 1.00 & 0 & 0 & 1.00 & 0 & 0 & 0 & 0 & 0 & 0 & 0 & 0 & 0 & 0 & 0 & 0 \\
\hline 5 & 0 & 0 & 0 & 1.00 & 0 & 0 & 0 & 0 & 0.90 & 0.12 & 1.00 & 0 & 0 & 0 & 0 & 0 & 0 & 0 \\
\hline \multicolumn{19}{|l|}{ Ark } \\
\hline $\mathrm{N}$ & 13 & 14 & 1 & 59 & 19 & 30 & 10 & 5 & 3 & 2 & 3 & 13 & 1 & 6 & 1 & 7 & 3 & 12 \\
\hline 1 & 0 & 0 & 0 & 1.00 & 1.00 & 0.03 & 0 & 0 & 1.00 & 1.00 & 1.00 & 1.00 & 1.00 & 1.00 & 0 & 1.00 & 0 & 1.00 \\
\hline 2 & 1.00 & 1.00 & 0 & 0 & 0 & 0.97 & 1.00 & 1.00 & 0 & 0 & 0 & 0 & 0 & 0 & 0 & 0 & 1.00 & 0 \\
\hline 3 & 0 & 0 & 1.00 & 0 & 0 & 0 & 0 & 0 & 0 & 0 & 0 & 0 & 0 & 0 & 1.00 & 0 & 0 & 0 \\
\hline \multicolumn{19}{|c|}{ Fum } \\
\hline $\mathrm{N}$ & 13 & 14 & 7 & 44 & 18 & 28 & 18 & 7 & 4 & 5 & 4 & 16 & 6 & 14 & 6 & 9 & 6 & 13 \\
\hline 1 & 0 & 0 & 0 & 0 & 0 & 0 & 0 & 0 & 0 & 0.10 & 0 & 0 & 0 & 0 & 0 & 0 & 0 & 0 \\
\hline 2 & 0 & 0 & 0 & 0 & 0 & 0 & 0 & 0 & 0 & 0.90 & 0 & 0 & 0 & 0 & 0 & 0 & 0.08 & 0 \\
\hline 3 & 1.00 & 0.07 & 0.21 & 0 & 0 & 0.84 & 0 & 0 & 1.00 & 0 & 0 & 0 & 1.00 & 0 & 0 & 1.00 & 0.92 & 0.906 \\
\hline 4 & 0 & 0 & 0.79 & 0 & 0 & 0 & 0 & 0 & 0 & 0 & 1.00 & 1.00 & 0 & 0 & 0 & 0 & 0 & 0 \\
\hline 5 & 0 & 0.93 & 0 & 1.00 & 1.00 & 0.16 & 1.00 & 1.00 & 0 & 0 & 0 & 0 & 0 & 1.00 & 0 & 0 & 0 & 0.04 \\
\hline 6 & 0 & 0 & 0 & 0 & 0 & 0 & 0 & 0 & 0 & 0 & 0 & 0 & 0 & 0 & 1.00 & 0 & 0 & 0 \\
\hline \multicolumn{19}{|l|}{ Gpi } \\
\hline $\mathrm{N}$ & 7 & 7 & 4 & 53 & 13 & 29 & 15 & 6 & 5 & 5 & 4 & 9 & 7 & 14 & 7 & 6 & 3 & 6 \\
\hline 1 & 0 & 0 & 0 & 0.01 & 0.89 & 0.03 & 0 & 0 & 0.10 & 0 & 0 & 0.33 & 0 & 0 & 0 & 0 & 0 & 0 \\
\hline 2 & 0 & 0 & 0 & 0 & 0 & 0.86 & 0 & 0.08 & 0.90 & 0 & 1.00 & 0 & 0 & 0 & 0 & 1.00 & 0 & 0 \\
\hline 3 & 0 & 0 & 0 & 0.88 & 0.11 & 0 & 0 & 0 & 0 & 0.60 & 0 & 0 & 0.86 & 0 & 0.93 & 0 & 0.67 & 0 \\
\hline 4 & 1.00 & 1.00 & 0 & 0 & 0 & 0.03 & 0.87 & 0.42 & 0 & 0 & 0 & 0.67 & 0 & 0.93 & 0 & 0 & 0 & 1.00 \\
\hline 5 & 0 & 0 & 0.75 & 0.10 & 0 & 0 & 0 & 0 & 0 & 0.40 & 0 & 0 & 0 & 0.07 & 0 & 0 & 0 & 0 \\
\hline 6 & 0 & 0 & 0.25 & 0 & 0 & 0.07 & 0.13 & 0.42 & 0 & 0 & 0 & 0 & 0.14 & 0 & 0.07 & 0 & 0.33 & 0 \\
\hline 7 & 0 & 0 & 0 & 0.01 & 0 & 0 & 0 & 0.08 & 0 & 0 & 0 & 0 & 0 & 0 & 0 & 0 & 0 & 0 \\
\hline \multicolumn{19}{|l|}{$H k$} \\
\hline $\mathrm{N}$ & 13 & 14 & 8 & 59 & 19 & 30 & 18 & 7 & 4 & 5 & 4 & 16 & 7 & 13 & 7 & 9 & 5 & 13 \\
\hline 1 & 0 & 0 & 0 & 0 & 0 & 0 & 0 & 1.00 & 0 & 0 & 0 & 0.19 & 0 & 1.00 & 0.64 & 0 & 1.00 & 0 \\
\hline 2 & 0 & 0 & 0 & 0.06 & 0 & 0 & 0 & 0 & 0 & 0 & 0 & 0 & 0 & 0 & 0 & 0 & 0 & 0 \\
\hline 3 & 0 & 0 & 1.00 & 0.93 & 0 & 0 & 1.00 & 0 & 0 & 0 & 0 & 0.03 & 1.00 & 0 & 0 & 1.00 & 0 & 1.00 \\
\hline 4 & 0 & 0 & 0 & 0.01 & 1.00 & 1.00 & 0 & 0 & 1.00 & 1.00 & 1.00 & 0.78 & 0 & 0 & 0.36 & 0 & 0 & 0 \\
\hline 5 & 1.00 & 1.00 & 0 & 0 & 0 & 0 & 0 & 0 & 0 & 0 & 0 & 0 & 0 & 0 & 0 & 0 & 0 & 0 \\
\hline \multicolumn{19}{|l|}{$M d h$} \\
\hline $\mathrm{N}$ & 13 & 12 & 7 & 38 & 12 & 30 & 17 & 7 & 5 & 5 & 4 & 13 & 5 & 10 & 5 & 9 & 5 & 13 \\
\hline 1 & 0 & 0 & 0 & 0 & 0 & 0 & 0 & 0 & 1.00 & 0 & 0 & 0 & 0 & 0 & 0 & 0 & 0 & 0.92 \\
\hline 2 & 0 & 0 & 1.00 & 0 & 0 & 1.00 & 1.00 & 1.00 & 0 & 0 & 0 & 0 & 1.00 & 1.00 & 1.00 & 1.00 & 0.90 & 0 \\
\hline 3 & 0 & 0 & 0 & 0 & 0 & 0 & 0 & 0 & 0 & 0 & 0 & 0.96 & 0 & 0 & 0 & 0 & 0 & 0.08 \\
\hline 4 & 0 & 0 & 0 & 0.99 & 0.71 & 0 & 0 & 0 & 0 & 0.90 & 1.00 & 0.04 & 0 & 0 & 0 & 0 & 0 & 0 \\
\hline 5 & 0 & 1.00 & 0 & 0 & 0 & 0 & 0 & 0 & 0 & 0.10 & 0 & 0 & 0 & 0 & 0 & 0 & 0.10 & 0 \\
\hline 6 & 0 & 0 & 0 & 0.01 & 0.29 & 0 & 0 & 0 & 0 & 0 & 0 & 0 & 0 & 0 & 0 & 0 & 0 & 0 \\
\hline 7 & 0.92 & 0 & 0 & 0 & 0 & 0 & 0 & 0 & 0 & 0 & 0 & 0 & 0 & 0 & 0 & 0 & 0 & 0 \\
\hline 8 & 0.08 & 0 & 0 & 0 & 0 & 0 & 0 & 0 & 0 & 0 & 0 & 0 & 0 & 0 & 0 & 0 & 0 & 0 \\
\hline \multicolumn{19}{|l|}{$M e$} \\
\hline $\mathrm{N}$ & 13 & 14 & 6 & 29 & 16 & 11 & 16 & 6 & 2 & 4 & 3 & 16 & 1 & 1 & 1 & 7 & 6 & 13 \\
\hline 1 & 0 & 0 & 0 & 0 & 0 & 0 & 0 & 0 & 0 & 0 & 0 & 0 & 1.00 & 0 & 0 & 0 & 1.00 & 1.00 \\
\hline 2 & 0 & 0 & 0 & 0 & 0 & 0 & 0 & 0 & 0 & 0 & 0 & 1.00 & 0 & 0 & 0 & 0 & 0 & 0 \\
\hline 3 & 0 & 0 & 0 & 0 & 0 & 0 & 0 & 0 & 0 & 0 & 0 & 0 & 0 & 1.00 & 0 & 0.93 & 0 & 0 \\
\hline 4 & 0 & 0 & 1.00 & 0 & 0 & 0 & 0 & 0 & 0 & 0 & 0 & 0 & 0 & 0 & 0 & 0.07 & 0 & 0 \\
\hline 5 & 0 & 0 & 0 & 0 & 0.06 & 0 & 1.00 & 0 & 0 & 0 & 0 & 0 & 0 & 0 & 0 & 0 & 0 & 0 \\
\hline 6 & 0 & 0 & 0 & 0.03 & 0.94 & 0.41 & 0 & 1.00 & 0.75 & 0.12 & 0 & 0 & 0 & 0 & 0 & 0 & 0 & 0 \\
\hline 7 & 0 & 0 & 0 & 0.97 & 0 & 0 & 0 & 0 & 0.25 & 0.88 & 1.00 & 0 & 0 & 0 & 0 & 0 & 0 & 0 \\
\hline 8 & 0 & 1.00 & 0 & 0 & 0 & 0.59 & 0 & 0 & 0 & 0 & 0 & 0 & 0 & 0 & 0 & 0 & 0 & 0 \\
\hline 9 & 1.00 & 0 & 0 & 0 & 0 & 0 & 0 & 0 & 0 & 0 & 0 & 0 & 0 & 0 & 1.00 & 0 & 0 & 0 \\
\hline
\end{tabular}




\begin{tabular}{|c|c|c|c|c|c|c|c|c|c|c|c|c|c|c|c|c|c|c|}
\hline & \multicolumn{18}{|c|}{$\begin{array}{c}\text { APPENDIX } 1 \\
\text { Continued }\end{array}$} \\
\hline & bea & $d e v$ & ran & lon & plon & $m i g$ & $d u b$ & tow & pun & $a b o$ & sha & pan & atr & $a b s$ & cay & ven & yen & tri \\
\hline \multicolumn{19}{|c|}{ Gpd } \\
\hline $\mathrm{N}$ & 1 & 1 & 6 & 1 & 1 & 1 & 13 & 1 & 1 & 2 & 4 & 1 & 4 & 1 & 5 & 1 & 5 & 1 \\
\hline 1 & 1.00 & 1.00 & 0 & 1.00 & 1.00 & 1.00 & 0 & 1.00 & 1.00 & 1.00 & 1.00 & 1.00 & 0 & 1.00 & 0 & 1.00 & 0 & 1.00 \\
\hline 2 & 0 & 0 & 1.00 & 0 & 0 & 0 & 0 & 0 & 0 & 0 & 0 & 0 & 1.00 & 0 & 0.40 & 0 & 0 & 0 \\
\hline 3 & 0 & 0 & 0 & 0 & 0 & 0 & 0 & 0 & 0 & 0 & 0 & 0 & 0 & 0 & 0.50 & 0 & 1.00 & 0 \\
\hline 4 & 0 & 0 & 0 & 0 & 0 & 0 & 1.00 & 0 & 0 & 0 & 0 & 0 & 0 & 0 & 0.10 & 0 & 0 & 0 \\
\hline \multicolumn{19}{|l|}{$I d h$} \\
\hline $\mathrm{N}$ & 1 & 1 & 1 & 14 & 1 & 30 & 11 & 1 & 5 & 5 & 4 & 1 & 6 & 1 & 5 & 1 & 4 & 1 \\
\hline 1 & 1.00 & 1.00 & 1.00 & 0 & 0 & 0 & 0 & 1.00 & 0 & 0 & 0 & 1.00 & 0.42 & 1.00 & 0 & 1.00 & 0.50 & 1.00 \\
\hline 2 & 0 & 0 & 0 & 0 & 0 & 1.00 & 1.00 & 0 & 0 & 0 & 1.00 & 0 & 0.58 & 0 & 1.00 & 0 & 0.50 & 0 \\
\hline 3 & 0 & 0 & 0 & 1.00 & 0 & 0 & 0 & 0 & 0 & 1.00 & 0 & 0 & 0 & 0 & 0 & 0 & 0 & 0 \\
\hline 4 & 0 & 0 & 0 & 0 & 1.00 & 0 & 0 & 0 & 1.00 & 0 & 0 & 0 & 0 & 0 & 0 & 0 & 0 & 0 \\
\hline
\end{tabular}


APPENDIX 2

Multiple sequence alignment of the last 285 basepairs of the mitochondrial cytochrome b gene in New World phlebotomine sand flies*

\begin{tabular}{|c|c|c|c|c|c|c|c|c|c|c|c|c|c|c|}
\hline & & & & & & & & & & & & & & \\
\hline B. devenanzii & $\mathrm{C}$ & $\mathrm{C} \mathrm{C}$ & $\mathrm{A} \mathrm{A}$ & A A A & $\mathrm{C} \mathrm{T} \mathrm{G}$ & G G G & G G A & G T A & A T T & G C T & $\mathrm{C} \mathrm{T} \mathrm{T}$ & G T T & A T A & $\mathrm{TCT}$ \\
\hline pertuyi & . & . $\mathrm{T}$ & . . . & &. $\mathrm{T}$ & . A & &. $\mathrm{T}$ & . . C & . . C & $\cdot$ & . . . & . . & . A \\
\hline L. $O$ & . & & . . . & . . & $\mathrm{T} \cdot \mathrm{A}$ & . A & . . . & . & . . . &.$\quad$. & $\mathrm{T} \cdot \mathrm{A}$ & & . & \\
\hline L. $t c$ & . & . $\mathrm{T}$ & . . . & . . & $\mathrm{T} \cdot \mathrm{A}$ & . . $\mathrm{A}$ & . . . & . & . & . . . & $\mathrm{T} \cdot \mathrm{A}$ & . & . & \\
\hline alpis & &. $\mathrm{T}$ & . . . & . . & $\mathrm{T} \cdot \mathrm{A}$ & . . . &. $\mathrm{T}$ & $\mathrm{T}$ & . & . . & . . . & .. & . . & \\
\hline L. $p$ & . & . $\mathrm{T}$ & . . . & & $\mathrm{T} \cdot \mathrm{A}$ & . . A & . . . & $\mathrm{T}$ & . . & . . A & . . . & . . A & . . . & A \\
\hline L. $t$ & . & . $\mathrm{T}$ & . . . & . . . & . . . & . . . & . . . & . & . . & . . . & . . . & . . . & . . . & . . $\mathrm{A}$ \\
\hline L. $r$ & & . $\mathrm{T}$ & . . . & . . . & . . $\mathrm{T}$ &. $\mathrm{T}$ & . . . & . & . . & . . C & $\mathrm{T} \cdot \mathrm{A}$ & . . A & . . . & \\
\hline. & & . A & . . . & . . G & T.A & . A & . . & . & . & . . A & $\mathrm{T} \cdot \mathrm{A}$ & . . . & 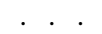 & \\
\hline & & $\mathrm{T}$ &.. & . . & $\mathrm{T} \cdot \mathrm{A}$ & . A &.. & . & . &.. & . . $\mathrm{A}$ & . . & . . & \\
\hline & & A & . . & & T.A & & & $\mathrm{T}$ & $\mathrm{C}$ & & & . & . . & \\
\hline & & . $\mathrm{T}$ &... & . . . &. $\mathrm{T}$ & . A & . . $\mathrm{T}$ & G & . . C & $\mathrm{C}$ & $\mathrm{T} \cdot \mathrm{A}$ & & & \\
\hline L. he & & . $\mathrm{T}$ & . . . & . . & . . $\mathrm{T}$ & . . . & . . $\mathrm{T}$ & . & $\mathrm{C}$ & . . C & $\mathrm{T} \cdot \mathrm{A}$ & & . & \\
\hline \multirow[t]{2}{*}{ L. panamensis } & . & . A & . . . & . . . & . . $\mathrm{T}$ & . . A & . . . & . & $\cdot$. & . . . & . . . & . . . & . . . & . . \\
\hline & 79 & & & & & & & & & & & & & \\
\hline anzii & A & A A & T C T & C A A & G G A & T T A & C A A & T T T & T A T & $\mathrm{C} \mathrm{C} \mathrm{T}$ & T T A & A A T & C A A & A $\mathrm{T} \mathrm{T}$ \\
\hline & . & . . & & . . . & . . . & . . & . . . & & . . C & . . C & . . . & . . C & . . . & . . C \\
\hline & . & . . & A T A & & . . C & & . . & . & . . . & . . A & . . . & . . . & . . . & \\
\hline & . & . . & A. C & . . & . . . & C. T & . . . & . & . . . & . . . & . . & . & . . . & \\
\hline & . & . . & $\mathrm{A} \mathrm{G} \mathrm{C}$ & . . & . . & T & . . . & . & . . & . . A & A. $T$ & . . &. & $\mathrm{C}$ \\
\hline & . & . & A G. & . . & . & C. T & . . . & & . . & . . A & A. . & . . . & . & \\
\hline L. $t$ & . & . & . T C & . . & . . $\mathrm{T}$ & $\mathrm{C} \cdot \mathrm{T}$ & . . . & . & . . & . . . & . . . & . . C & . . & \\
\hline L. $r$ & . & . . & A. . & . . . & . . . & . . . & . . . & & . . . & . . A & . . . & . . . & . . & \\
\hline & . & & A T A & . . . & . . . & . . . & . . . & & . . C & . . . & . . . & & 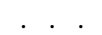 & \\
\hline & 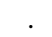 & . G & $\mathrm{AGT}$ & . . & . . C & $\mathrm{C} \cdot \mathrm{T}$ & . . . & & . . C & . . A & G. . & & . & \\
\hline & . & . $\mathrm{T}$ & & & . . G & C. T & . . . & $\mathrm{C}$ & & & A. $T$ & G C. & . & \\
\hline L. $v$ & . & . . & A A. & & . . . & C. C & . . & & $\mathrm{C}$ & . . A & A. T & . . . & . & \\
\hline L. $h$ & . & . & A A. & & . . & C. C & . . & & . & . . A & A. $T$ & & 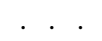 & \\
\hline \multirow[t]{2}{*}{ L. panamensis } & . & . & A A . & . . & . . & . . . & . . & . & . . & . . A & . . . & & . . & . . \\
\hline & & & & & & & & & & & & & & \\
\hline & $\mathrm{T}$ & G A & A $\mathrm{T} \mathrm{T}$ & G G G & $\mathrm{GCT}$ & $\mathrm{CG} \mathrm{T}$ & $\mathrm{C} \mathrm{C} \mathrm{T}$ & G T A & G A A & G A C & $\mathrm{C} \mathrm{C} \mathrm{C}$ & $\mathrm{T}$ A C & $\mathrm{G} T \mathrm{~T}$ & $\mathrm{CT} \mathrm{T}$ \\
\hline & 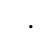 & . . & . . . & . . A & . . . & . G & . . . & . . . & . . . & A. . & . . . & . . $\mathrm{T}$ & A. $\mathrm{C}$ & \\
\hline & 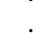 & . & & . . A & . . C & . $\mathrm{C}$ & & & & . & &. $\mathrm{T}$ & A. $\mathrm{C}$ & $\mathrm{T}$. \\
\hline & . & . & & . . A & . . C & & . . A & & & & . . $\mathrm{T}$ & $\mathrm{T}$ & A. . & $\mathrm{T}$. \\
\hline & . & . & . . . & . . $\mathrm{A}$ & . . $\mathrm{A}$ & & . . . & $\mathrm{T}$ & G & & . . $\mathrm{T}$ & & . . & $\mathrm{T}$. \\
\hline L. $H$ & . & . & . . . & . . A & . . . & . . A & . $\mathrm{A}$ & $\mathrm{T}$ & . & & . & & & \\
\hline$L$. & . & . & . . . & . . $\mathrm{T}$ & . . A & . . G &.. & & & & . . $\mathrm{T}$ & & A. . & $\mathrm{T}$. \\
\hline & . & . & . . . & . . A & . . A & . . C & . . . & $\mathrm{T}$ & . & & . . A & & A. & $\mathrm{T}$. \\
\hline & . & . & . . . & . . $\mathrm{T}$ & . . . & . . C & . . . & & . & & . . $\mathrm{T}$ & . $\mathrm{T}$ & A. . & $\mathrm{T} \cdot \mathrm{A}$ \\
\hline & 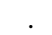 & . & . . . & . . . & . . A & . . C & . . . & $\mathrm{T}$ & . & & . . . &. $\mathrm{T}$ & A. . & A. \\
\hline & . & . & . . & . . A & . . C & . A & . & $\mathrm{T}$ & 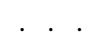 & & $\therefore \mathrm{T}$ & & . & \\
\hline & . & . & & . . A & . . A &. $\mathrm{G}$ & & $\mathrm{T}$ & & & . . &. $\mathrm{T}$ & A. C & \\
\hline L. hernandezi & . & . & . . C & . . A & . . A &. $\mathrm{G}$ & & $\mathrm{T}$ & & & . . $\mathrm{T}$ & . . $\mathrm{T}$ & A. . & \\
\hline \multirow[t]{2}{*}{ L. panamensis } & . & . & . . . & . . A & . . C & . . $\mathrm{A}$ & . . A & $\mathrm{T}$ & . . $\mathrm{G}$ & . C A & . . $\mathrm{T}$ &.$\quad \mathrm{T}$ & A. C & A. \\
\hline & & & & & & & & & & & & & & \\
\hline & A & $\mathrm{T} \mathrm{T}$ & $\mathrm{T} \mathrm{A}$ & A A T & $\mathrm{C} \mathrm{C} \mathrm{T}$ & T T A & A T T & $\mathrm{TC} \mathrm{T}$ & A A A & A T T & T G A & G A T & A A T & $\mathrm{A} \mathrm{A} \mathrm{T}$ \\
\hline & . & . $\mathrm{C}$ & & & . . . & . . & & . . & . . . & & . . . & & 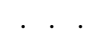 & \\
\hline & . & $\mathrm{C}$ & . & &. $\mathrm{G}$ & C. T & & & & & . & & . A & \\
\hline & . & $\mathrm{C}$ & A C. & $\mathrm{C} \mathrm{C}$ & & . . . & & & . & & . . & & . . A & \\
\hline & . & & A. $T$ & &. & A. $T$ & G. C & A & & & .. & & . A & C. \\
\hline & & $\mathrm{C}$ & A. T & $\mathrm{C}$ & & A. $T$ & . . $\mathrm{C}$ & $\Delta$ & & & & & & $\mathrm{C} \mathrm{C}$ \\
\hline L. & & . & . . C & &. $\mathrm{A}$ & A. & & C & $\mathrm{T} \cdot \mathrm{T}$ & T. A & . . . & &..$A$ & \\
\hline & $\mathrm{T}$ & . & A. . & & . . $\mathrm{A}$ & A. . & & . . $\mathrm{A}$ & . $\mathrm{T} \mathrm{T}$ & & . . & & . . A & \\
\hline & . & . & A. C & & . . . & & & . . . & $\mathrm{T} \mathrm{T}$. & $\mathrm{TA}$. & . . & & $\cdot A$ & \\
\hline & . & . & A. $T$ & & . . A & G. & G. C & & . . . & & . . & . . C & . . A & $\mathrm{C}$ \\
\hline & & . & A.. & G C &.. & A. C & . GA & & & & & & . C A & \\
\hline & & . & A. $\mathrm{T}$ & 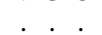 & & A. . & G. A & & & & & & G & T A. \\
\hline & . & . & A. $T$ &.. $\mathrm{C}$ & & A & G. A & A & & & . & & . . . & T A. \\
\hline L. panamensis & . & . . & $\mathrm{T}$. & $\mathrm{C}$ & & A.. & G. . & A & & & . . & & . . & T A \\
\hline
\end{tabular}


APPENDIX 2

Continued

\begin{tabular}{|c|c|c|c|c|c|c|c|c|c|c|c|c|c|c|}
\hline & 40 & & & & & & & & & & & & & \\
\hline B. devenanzii & A & $\mathrm{T} \mathrm{C}$ & G C A & A $\mathrm{T} \mathrm{T}$ & T T A & T T T & T T C & $\mathrm{C} \mathrm{T} \mathrm{G}$ & $\mathrm{C} \mathrm{C} \mathrm{T}$ & T T C & C T G & $\mathrm{CAC}$ & T T A & A A T \\
\hline B. beaupertuyi & . & . $\mathrm{T}$ & . . . & . . C & . . . & . . C & . . $\mathrm{T}$ & . . $\mathrm{T}$ & . . C & . . $\mathrm{T}$ & T. A & . . $\mathrm{T}$ & $\cdot$ & \\
\hline L. ovallesi & . & . $\mathrm{T}$ & . . . & . . $\mathrm{C}$ & $\mathrm{C}$. & . . . & . . A & . . C & . . A & A. $T$ & . . $\mathrm{T}$ & . . $\mathrm{T}$ & A. & . G A \\
\hline L. townsendi & . & . $\mathrm{T}$ & . . $\mathrm{T}$ & . . $\mathrm{C}$ & C. . & . . . & . . A & $\mathrm{T} \cdot$ & . . A & A. $T$ & . . $\mathrm{T}$ & . . $\mathrm{T}$ & A. . & . G. \\
\hline L. longipalpis & . & . $\mathrm{T}$ &. $\mathrm{T}$ &... & . . . & . . . &. $\mathrm{T}$ & . . C & . . A & A. T & . . $\mathrm{T}$ &. $\mathrm{T}$ & $\mathrm{AC} \mathrm{T}$ & . G \\
\hline L. pseudolongipalpis & . & . $\mathrm{T}$ & . . $\mathrm{T}$ & & . . . & . . . & . . $\mathrm{T}$ & . . C & . . A & $\mathrm{T}$ & . . C & . . $\mathrm{T}$ & A C . & . G. \\
\hline L. trinidadensis & . & & . . $\mathrm{T}$ & . & . . . & . . C & . . $\mathrm{T}$ & . . C & . . G & A. T & . . C & . . $\mathrm{T}$ & A A T & . G A \\
\hline L. migonei & . & . $\mathrm{T}$ & . . . & . & . . . & . . . & . . $\mathrm{T}$ & . . $\mathrm{T}$ & . . C & $\mathrm{T}$ & . . $\mathrm{T}$ & . . $\mathrm{T}$ & A. . & . GA \\
\hline L. cayennensis & . & . $\mathrm{T}$ & . . C & . & . . . & . . . & . . $\mathrm{T}$ & $\mathrm{T} \cdot \mathrm{A}$ & . . C & $\mathrm{T}$ & $\mathrm{T} \cdot \mathrm{A}$ & & $\mathrm{CA}$ & . G A \\
\hline L. gomezi & . & . $\mathrm{T}$ & . $\mathrm{T}$ & . & . . . & . . C & . . . & $\mathrm{T} \cdot \mathrm{A}$ & . . C & A & A C C & . . $\mathrm{T}$ & A. & . GA \\
\hline L. dubitans & . & . $\mathrm{T}$ & . . & & . . . & . . . &. $\mathrm{T}$ & . . $\mathrm{T}$ & . . . & A. . & $\mathrm{T} \cdot \mathrm{A}$ & . . $\mathrm{T}$ & . . & . G . \\
\hline L. whitmani & . & . $\mathrm{T}$ & . . & . . & C. G & . . . & . . $\mathrm{T}$ & . . C & . . . & A. T & T.A & . . $\mathrm{T}$ & A. & . GA \\
\hline L. hernandezi & . & . $\mathrm{T}$ & . . & . . . & C. C & . . . &. $\mathrm{T}$ & . . $\mathrm{T}$ & . . . & A. T & $\mathrm{T} \cdot \mathrm{A}$ & . . $\mathrm{T}$ & A . & . G A \\
\hline \multirow[t]{2}{*}{ L. panamensis } & . & . $\mathrm{T}$ & . . . & . . C & $\mathrm{C}$. & . . . & . . $\mathrm{T}$ & . . $\mathrm{T}$ & . . A & A. $\mathrm{T}$ & . . $\mathrm{T}$ & . . $\mathrm{T}$ & A C & . G A \\
\hline & 118 & & & & & & & & & & & & & \\
\hline B. devenanzii & $\mathrm{T}$ & $\mathrm{T}$ A & T T T & T G A & T A T & A T A & G T A & A T T & A T T & A T T & A T C & C T T & T T A & $\mathrm{ACC}$ \\
\hline B. beaupertuyi & . & . . & . . C & . . . & . . . & . . . & . . . & . . . & . . . & & . . . & . . C & . . . & . $\cdot \mathrm{A}$ \\
\hline L. ovallesi & . & . . & . . . & & . . . & . . . & $\mathrm{T}$. & . . . & . . . & $\mathrm{G} \cdot \mathrm{A}$ & . . T & $\mathrm{T} \cdot \mathrm{A}$ & . . G & . . A \\
\hline L. townsendi & . & . . & . . . & . & . . . & C.. & $\mathrm{T}$. & . . . & . . . & G.A & C. T & T.A & . . . & . . . \\
\hline L. longipalpis & . & . . & . . . & . . & . . . & . . . & $\mathrm{T} \cdot \mathrm{T}$ & . . & . . . & G. A & . . $\mathrm{T}$ & T.A & . . . & . . A \\
\hline L. pseudolongipalpis & . & . . & . . & . & . . . & . . & $\mathrm{T} \cdot \mathrm{T}$ & . . . & . . . & G.A & . . $\mathrm{T}$ & T.A & . & . . A \\
\hline L. trinidadensis & & . . & . . . & & . . & . . & $\mathrm{T}$. & . . A & & G. A & . . $\mathrm{T}$ & $\mathrm{T} \cdot \mathrm{A}$ & . . . & . . $\mathrm{T}$ \\
\hline L. migonei & & . . & $\cdot$. & . & . . & . . . & . . $\mathrm{T}$ & . . . & . C. & & . . $\mathrm{T}$ & $\mathrm{T} \cdot \mathrm{A}$ & . . & . . . \\
\hline L. cayennensis & $\mathrm{C}$ & . . & . . & . & . . & . . . & $\mathrm{T} \cdot \mathrm{T}$ & $\mathrm{G}$. & . . . & G. A & . . $\mathrm{T}$ & . . . & . . & . . $\mathrm{A}$ \\
\hline L. gomezi & & . & . . & . & . . . & . . & $\mathrm{T} \cdot \mathrm{T}$ & G. . & . . . & & . . . & . . A & . & . . $\mathrm{T}$ \\
\hline L. dubitans & G & . . & . . & . & . . . & . . & $\mathrm{T}$. & . . & . . . & G. A & . . $\mathrm{T}$ & $\mathrm{T} \cdot \mathrm{A}$ & . & . . A \\
\hline L. whitmani & . & . . & . . & & . . C & . . & $\mathrm{T}$. & . . & . . . & & . . $\mathrm{T}$ & $\mathrm{T} \cdot \mathrm{A}$ & . . . & . . $\mathrm{T}$ \\
\hline L. hernandezi & . & & . . & . &.$\quad$. & . . . & $\mathrm{T} \cdot$ & . . . & . . . & & . . $\mathrm{T}$ & $\mathrm{T} \cdot \mathrm{A}$ & . . G & . . $\mathrm{T}$ \\
\hline \multirow[t]{2}{*}{ L. panamensis } & · & & . . & . & . . . & & $\mathrm{T} \cdot \mathrm{T}$ & . . & . . . & G. A & . . $\mathrm{T}$ & $\mathrm{T} \cdot \mathrm{A}$ &.$\quad$. & . . A \\
\hline & 196 & & & & & & & & & & & & & \\
\hline B. devenanzii & A & $\mathrm{CT}$ & G G C & C A A & A T T & C T T & $\mathrm{ACT}$ & G T T & C T C & $\mathrm{T} \mathrm{A} \mathrm{T}$ & T T T & $\mathrm{G} \mathrm{C} \mathrm{T}$ & T A T & $\mathrm{T} \mathrm{A} \mathrm{T}$ \\
\hline B. beaupertuyi & . & . . &. $\mathrm{T}$ & . . G & . . . & . . A & . . . & . . . &. $\mathrm{T}$ & & . . . & & & \\
\hline L. ovallesi & . & . A & . . . & . . . & . . . & $\mathrm{T} \cdot \mathrm{A}$ & . . A & . . . & A. T & & . . . & T T A & . . C & . . . \\
\hline L. townsendi & . & . A &.$\quad \mathrm{T}$ & & . . . & $\mathrm{T} \cdot \mathrm{A}$ & . . . & . . . & G. T & & . . $\mathrm{C}$ & C T A &.$\quad$. &.$\quad \mathrm{C}$ \\
\hline L. longipalpis & . & & . . $\mathrm{T}$ & & . . . & T.A & . . . & . . A & . . $\mathrm{T}$ & & . . . & T T A & . . . & . . . \\
\hline L. pseudolongipalpis & . & . A & . . $\mathrm{T}$ & . . & . . & $\mathrm{T} \cdot \mathrm{A}$ & . . . & . . C & . . $\mathrm{T}$ & $\mathrm{C}$ & . . . & T T A & . . & . . \\
\hline L. trinidadensis & . & . A & . . A & & . . & T.A & . . A & . . . & G. . & & .. . & $\mathrm{T} \mathrm{T} \mathrm{A}$ & . & . . \\
\hline L. migonei & . & & . . $\mathrm{T}$ & & . . . & $\mathrm{T} \cdot \mathrm{A}$ & . . . & . . . & A. T & $\mathrm{C}$ & . . . & A T A & . . &. $\mathrm{C}$ \\
\hline L. cayennensis & . & . A & . . A & & . . C & . . C & . . . & A. . & A. T & . & . . . & A T A & . . &. $\mathrm{C}$ \\
\hline L. gomezi & . & . . & . . $\mathrm{T}$ & & . . C & T.A & . . A & . . . & A. $\mathrm{T}$ & & & $\mathrm{T} \mathrm{T} A$ & . $\mathrm{C}$ & \\
\hline L. dubitans & . & & . . A & . & . . $\mathrm{C}$ & . . . & . . C & . . A & A. T & & . . & T T A & . & . $\mathrm{T}$. \\
\hline L. whitmani & . & . $\mathrm{C}$ & . . A & & T.A & $\mathrm{T} \cdot \mathrm{A}$ & . . . & . . . & A. $T$ & & . . . & $\mathrm{C} \mathrm{T}$. & . & . \\
\hline L. hernandezi & . & . . & . . A & & $\mathrm{T} \cdot \mathrm{A}$ & $\mathrm{T} \cdot \mathrm{A}$ & . . . & . . . & A. T & $\mathrm{C}$ & & $\mathrm{C} \mathrm{T}$ & & . \\
\hline \multirow[t]{2}{*}{ L. panamensis } & . & & . . . & & $\mathrm{T} \cdot \mathrm{A}$ & $\mathrm{T} \cdot \mathrm{G}$ & . . A & A. . & A. T & & & A T A & & . \\
\hline & 274 & & & & & & & & & & & & & \\
\hline B. devenanzii & $\mathrm{T}$ & $\mathrm{T}$ A & A A C & A A $\mathrm{T}$ & T A A & & & & & & & & & \\
\hline B. beaupertuyi & . & . . & $\mathrm{C}$. & & . . . & & & & & & & & & \\
\hline L. ovallesi & . & & . . . & C. A & . . . & & & & & & & & & \\
\hline L. townsendi & . & . . & . . $\mathrm{T}$ & C. A & . . G & & & & & & & & & \\
\hline L. longipalpis & & & . . $\mathrm{T}$ & & . . G & & & & & & & & & \\
\hline L. pseudolongipalpis & $\mathrm{C}$ & . $\mathrm{T}$ & . . . & C. C & . . G & & & & & & & & & \\
\hline L. trinidadensis & $\mathrm{C}$ & . $\mathrm{T}$ & & . C A & . . . & & & & & & & & & \\
\hline L. migonei & . & . . & .. $\mathrm{T}$ & C. A & . . & & & & & & & & & \\
\hline L. cayennensis & . & & . . $\mathrm{T}$ & . . . & . . . & & & & & & & & & \\
\hline L. gomezi & . & . . & . . $\mathrm{T}$ & & . . G & & & & & & & & & \\
\hline L. dubitans & . & . . & . . $\mathrm{T}$ & . . & . . . & & & & & & & & & \\
\hline L. whitmani & & & G C A & . & . . & & & & & & & & & \\
\hline L. hernandezi & $\mathrm{C}$ & & G C A & & . . & & & & & & & & & \\
\hline L. panamensis & $\cdot$ & & T C A & . . . & . . . & & & & & & & & & \\
\hline
\end{tabular}

